ОСОБЛИВОСТІ ЗДОРОВОЇ ПОВЕДІНКИ В МОЛОДІЖНОМУ СЕРЕДОВИЩІ: ГЕНДЕРНИЙ АСПЕКТ

\title{
PECULARITIES OF HEALTHY BEHAVIOUR IN YOUTH ENVIRONMENT: GENDER ASPECT
}

УдК 159.922.1:159.9.019.4- 053.6 (043.2) DOI https://doi.org/10.32843/26635208.2020 .15 .42

Марценюк М.О.

к.психол.н., старший викладач касредри психології

Мукачівський державний університет у статті розглядається популярне питання нашого сьогодення - здоров'я особистості, що набуває все більшого значення в житті кожної людини та суспільства в цілому. Оскільки здоров'я людини є досить складним феноменом і динамічним явищем, то постає актуальне питання про дослідження та виявлення механізмів, які орієнтують людину на здоровий спосіб життя, здорову поведінку, пропагують превентивну поведінку, особливо серед дітей і юнацтва. Відзначається, що збереження й зміцнення здоров'я молодого покоління $\epsilon$ важливою проблемою й турботою будь-якої сім'ї, держави та справедливо вважається багатством нації, яка покладає надії в подальшому прогресивному розвитку на своїх нащадків. Знання й ставлення до здоров'я $\epsilon$ ключовим фрактором, який визначає ставлення людини до свого життя.

Обгрунтовано методологію здійснення пси хологічного дослідження особливостей гендерного аспекту здорової поведінки в молодіжному середовищі. Для цього були обрані методики, що досліджують такі параметри, як-от: загальний показник схильності до порушення здорового способу життя й окремих його параметрів; індивідуальні особливості особистості й психічних станів; рівень здійснення свідомого самоконтролю й саморегуляції власної поведінки, думок і почуттів; специоріка дії механізмів психологічного захисту.

Висвітлено й проаналізовано емпірично досліджені гендерні особливості здорової поведінки дівчат і хлопців. Визначено, як вони бачать здоров'я та здоровий спосіб життя, який спосіб життя вони ведуть, які параметри здорового способу життя вони порушують. Описано в порівнянні уявлення юнаків і дівчат про здорову поведінку, те, як гендерні стереотипи впливають на їхню повсякденну поведінку стосовно власного здоров'я. Встановлено, що в цілому молодь має правильне, адекватне уявлення про життєвий зміст понять «здоровий спосіб життя» $i$ «нездоровий спосіб життя» з їхніми соціально-психологічними наслідками. Наголошено на необхідності здійснення заходів пропагування психогігієнічного виховання та здорового способу життя серед молоді через засоби масової інсрормації й такі соціальні інститути, як сім'я, друзі, ровесники та інші.
Ключові слова: здоров'я, молодь, психологічне здоров'я, здоровий спосіб життя, гендерні стереотипи, пропаганда ЗСЖ, психогігієнічне виховання.

The article deals with the popular question of our present - health of personality, which is gaining increasing importance in life of each person and society in general. Since human health is a rather complex phenomenon and a dynamic process, the actual question about the research arises. This refers to identification of mechanisms that orient person to a healthy lifestyle, healthy behavior, and promote preventive behavior, especially among children and young people. It is noted that the preservation and strengthening of the younger generation heath is an important problem and care of any family, state, and is fairly considered the wealth of the nation, which puts hopes for further progressive development on their descendants. Knowledge and attitude to health are the key factors in determining a person's attitude to life. The methodology of the psychological study of the gender aspect features of healthy behavior in the youth environment is substantiated. For this purpose, methods have been selected that examine such parameters as: the general indicator of predisposition to a violation of a healthy lifestyle and its individual parameters; individual peculiarities of personality and mental states; level of conscious self-control and self-regulation of own behavior, thoughts and feelings; the specifics of psychological protection mechanisms. The gendered features of girls and boys healthy behavior are empirically investigated and analyzed. It is determined how they see health and a healthy lifestyle, what lifestyle do they lead, which parameters of a healthy lifestyle they break. Comparison of girls and boys idea about healthy behavior and how gender stereotypes affect their everyday behavior in relation to their own health are described. It is established that young people in general have a correct, adequate idea about the meaning of vital concepts "healthy lifestyle" and "unhealthy lifestyle" with their socio-psychological consequences. It was emphasized on the necessity of carrying out measures to promote psycho-hygienic education and healthy lifestyle among young people through mass media and social institutions such as family, friends, peers, and others.

Key words: health, youth, psychological health, healthy lifestyle, gender stereotypes, promotion of healthy lifestyle, psycho-hygienic upbringing.
Постановка проблеми. Здоров'я в житті кожної людини та суспільства набуває сьогодні все більшої ваги. Центр профілактичних зусиль сьогодні зміщується з конкретних розладів на загальне зміцнення здоров'я. Все більшого значення набувають дослідження здоров'я в контексті гуманітарних дисциплін, особливо соціальної психології, яка займається вивченням механізмів, що орієнтують на здоровий спосіб життя, пропагуванням превентивної поведінки.

Показники здоров'я розглядаються в сучасному соціумі як кумулятивні індикатори рівня добробуту суспільства в цілому й окремих 
його прошарків. Численні дослідження показують, що стан здоров'я людей в Україні постійно погіршується, тому збереження й зміцнення здоров'я людини $€$ актуальною проблемою й турботою нашої держави.

Видатний український учений М.М. Амосов стверджував, що здоров'я людини $є$ досить складним феноменом і може розглядатися як філософська, соціально-економічна, біологічна, медична, соціально-психологічна категорія, як об'єкт споживання, внесення капіталу, як індивідуальна й суспільна цінність, явище динамічне, системного характеру, яке постійно взаємодіє з навколишнім середовищем, що своєю чергою також постійно змінюється [1].

Аналіз останніх досліджень і публікацій. Проблема здоров'я особистості привертає увагу багатьох науковців. Так, серед вітчизняних і зарубіжних дослідників питання, пов'язані з різними аспектами психічного здоров'я, вивчали О.В. Алєксєєв (настрій і здоров'я); М.Й. Боришевський (психологія самоактивності й суб'єктного розвитку особистості як саморегульованої соціально-психологічної системи); Б.С. Братусь (аномалії особистості); І.В. Дубровіна (психологічне здоров'я учасників освітнього процесу); Л.Д. Дьоміна, І.О. Ральникова (психічне здоров'я та захисні механізми особистості); Г.В. Ложкін, М.І. Мушкевич, О.В. Наскова, І.В. Толкунова (психологія здоров'я людини); С.Д. Максименко (генетична психологія); Г.С. Нікіфоров (психологія здоров'я); В.М. Панкратов (саморегуляція психічного здоров'я); Д.Д. Федотов (збереження психічного здоров'я); О.В. Хухлаєва (особливості психічного здоров'я студентів); О.Я. Чебикін (проблема емоційної стійкості) та інші. Серед цілого ряду авторських позицій переважають наукові погляди, згідно з якими психологічне здоров'я тлумачиться як здатність особистості до самореалізації, самоактуалізації, адекватного самоприйняття себе та світу. Цієї точки зору дотримуються В. Франкл, А. Маслоу (психологічне здоров'я як здатність особистості до самореалізації, самоактуалізації); А. Адлер, Е. Фромм (міжособистісні стосунки як важливий критерій психічного та психологічного здоров'я), а також С. Москович, К. Ерзміш, які проблему хвороби та здоров'я розглядають через призму теорії соціальних уявлень.

Проблема формування здорового способу життя розкривається в соціальних дослідженнях Т.В. Бондар, О.Г. Карпенко, О.О. Яременко, О.М. Балакирєвої, В.С. Фоміна та інших; у психологічних дослідженнях С.Д. Максименка, І.В. Коваль, С.І. Болтівця, О.М. Кокуна, Т.М. Титаренко, Л.І. Лєпіхової, О.С. Кляпець, О.Ф. Бондаренка, В.Д. Менделевича, І.Ф. Мягкова, П.І. Сидорова, Т.С. Яценко та ряду інших вітчизняних науковців.
Постановка завдання. Мета нашої роботи полягає в теоретичному аналізі й емпіричному дослідженні особливостей порушень здорової поведінки в молодіжному середовищі, зокрема його гендерного аспекту. Для організації роботи застосовувалися теоретичні методи дослідження (теоретичний аналіз і систематизація науково-теоретичних джерел) й емпіричні методи, зокрема стандартизовані методики «Опитувальник порушень здорової поведінки» О.Л. Луценко й О.Є. Габелкової, тест-опитувальник «Дослідження вольової саморегуляції» А.В. Звєрькова та Є.В. Ейдман, опитувальник «Міні-мульт» (скорочений багатофакторний опитувальник для дослідження особистості MMPI в адаптації В.П. Зайцева та В.Н. Козюлі), опитувальник «Індекс життевого стилю» (Плутчик - Келлерман - Конте), а також статистичні методи оброблення й інтерпретації даних.

Виклад основного матеріалу дослідження. Серед великої кількості ролей, що їх засвоює людина, для нормальної соціалізації особистості велике значення мають статеві та гендерні ролі. Ці ролі тісно пов'язані з усвідомленням себе представником певної статі з нормативами поведінки, характерної для представників цієї статі. Гендерні ролі не виникають одразу з народженням дитини, вони розвиваються залежно від багатьох умов і факторів протягом людського життя. Цей розвиток має свої закономірності, суперечності. Від нього залежить характер життєвого сценарію людини, стиль життя та стратегії поведінки в різноманітних життєвих ситуаціях.

Гендер (англ. gender - «стать», від лат. genus - «рід») - соціально-біологічна характеристика, через яку визначаються поняття «чоловік» і «жінка», психосоціальні, соціокультурні ролі чоловіка й жінки як особистостей, на відміну від статі, яка позначає біологічні відмінності, цілісна психічна репрезентація статі, сповнена неповторним динамічним глибинним, когнітивним і поведінковим поняттям жіночого й чоловічого, здобута індивідом у результаті набуття індивідуального гендерного досвіду. Тобто такий соціальний конструктор, що визначає соціальну стать людини [2, с. 132-155]. На відміну від біологічної статі гендер $є$ набором соціально-рольових самоідентифікацій (самовизначень), які можуть збігатись із суто біологічними статеворольовими стереотипами або суперечити їм [5, c. 299-300].

Гендерна ідентичність - це переживання власної відповідності гендерним ролям, тобто сукупностям суспільних норм і стереотипів поведінки, характерним для представників певної статі (аботаким, щоприписуютьсяпредставникам певної статі суспільно-історичною чи соціокультурною ситуацією) [2, с. 132-155]. 
Ми звикли вважати чоловіків і жінок абсолютно різними істотами. Найменшим відмінностям у будові головного мозку представників різних статей учені схильні надавати набагато більшого значення, ніж на те дають право об'єктивні дані. Зазвичай автори праць із психології посилаються на чотири психологічні відмінності між статями: здатність орієнтуватись у просторі, математичні здібності, мовні навички й агресивність.

Як відомо, передумовою конструювання гендеру та гендерної поведінки є гендерні стереотипи - уявлення про якості й норми поведінки чоловіків і жінок. Оскільки кожна людина, незалежно від гендерної приналежності, $€$ індивідуальністю зі своїм набором психологічних якостей і властивостей, співвідношенням маскулінності й фемінності у психіці, розуміння гендерного стереотипу надзвичайно важливо. Це допоможе кожній індивідуальності й суспільству в цілому стати більш продуктивним, гармонійним і розвиватися в будь-якій сфері діяльності.

Гендерні стереотипи формуються, як вважають дослідники, починаючи 3 раннього дитячого віку, в процесі так званої соціалізації - засвоєння панівних у культурному середовищі уявлень про правильну поведінку, розподіл здібностей і обов'язків тощо. Підсумком соціалізації є засвоєння певної соціальної ролі [4, с. 16-17].

Сучасними українськими науковцями С.Д. Максименко, С.І. Болтівець, І.В. Коваль, О.М. Кокун, Т.М. Титаренко, Л.А. Лєпіхова, О.Я. Кляпець було виявлено: гендерні стереотипи сприяють тому, що хлопці схильні, нерідко нехтуючи своїм здоров'ям, наслідувати «взірці справжніх чоловіків», які нібито обов'язково повинні палити, вживати алкоголь, завжди схильні до невмотивованої агресії та безладних сексуальних зв'язків. На жаль, хлопці не готові брати на себе відповідальність за своє здоров'я й не вважають себе відповідальними за здоров'я своїх близьких, своїх майбутніх нащадків. Тотальний гедонізм, який плекає реклама в засобах масової інформації (далі - ЗМІ), детермінує індиферентне чи навіть вороже ставлення молодих людей до здорового способу життя, в якому вони не бачать жодного сенсу. Дівчата своєю чергою орієнтуються на інші гендерні стереотипи, які штовхають їх до переоцінки ролі зовнішності, «тілесної натури». Саме приваблива зовнішність, молоде тіло можна вигідно продати, за їхньою допомогою можна швидко досягти успіху, заробити багато грошей, зробити кар'єру, знайти собі надійного й довготривалого «спонсора» чи навіть вдало вийти заміж. За таких умов молода жінка часто забуває про почуття власної гідності. Ї̈̈ самоцінність, самодостатність якимось дивним чином викривлюються Ця ситуація провокує формування настанов на нездоровий спосіб життя, ризиковані контакти. Дівчатам більше притаманна не агресія, як хлопцям, а аутоагресія. Вони готові терпіти, страждати, чекати мовчки, поки щось зміниться на краще, ризикувати своїм здоров'ям знов і знов. Почуття спустошеності, зневіреності живить комплекс жертви, що нерідко сприяє ранньому виникненню психосоматичних розладів [7].

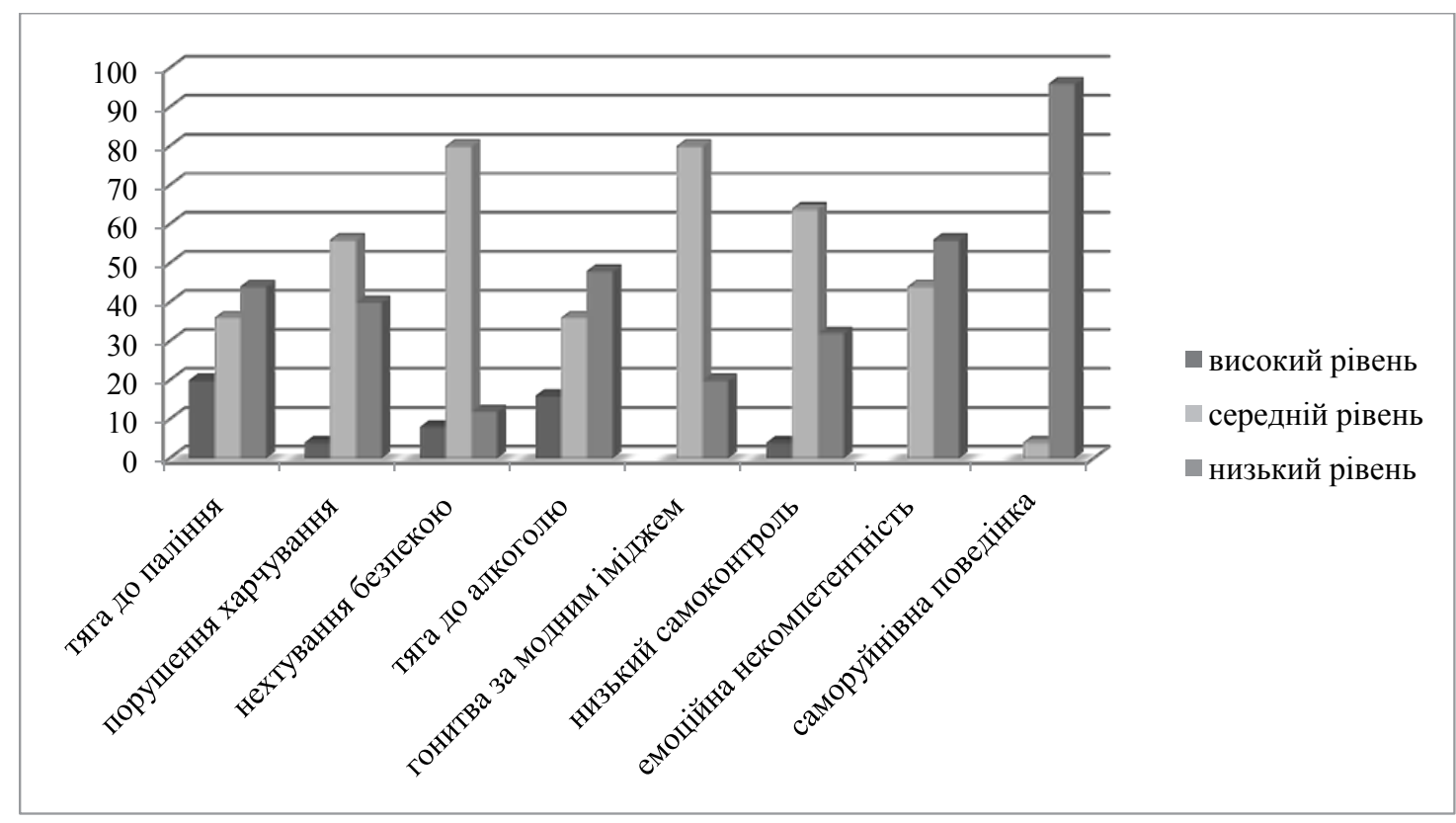

Рис.1. Показники порушення здорової поведінки в юнаків за методикою “Опитувальник порушення здорової поведінки» О.Л. Луценко й О.Є. Габелкової (у \%) 
I оскільки нам було важливо дослідити й проаналізувати те, як бачать здоров'я та здоровий спосіб життя юнаки й дівчата, чи $€$ відмінності в їхніх уявленнях про здорову поведінку, як гендерні стереотипи впливають на їхню повсякденну поведінку стосовно власного здоров'я, який спосіб життя вони ведуть, які параметри здорового способу життя вони порушують і які саме відмінні риси притаманні їм, вибірку дослідження становили юнаки й дівчата 16-19 років в кількості 50 осіб.

Так, за «Опитувальником порушень здорової поведінки» О.Л. Луценко й О.Є. Габелкової було виявлено: хлопцям більше харак-

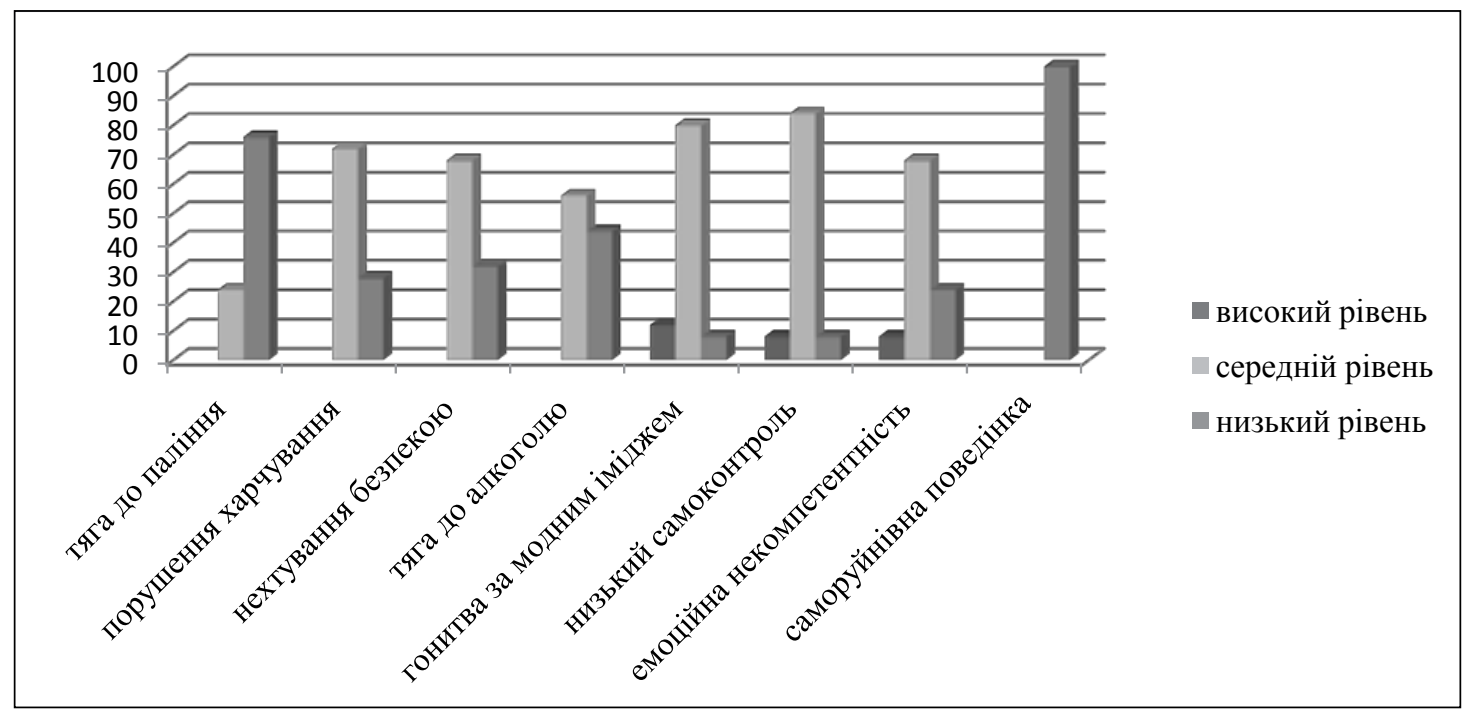

Рис. 2. Показники порушення здорової поведінки в дівчат за методикою «Опитувальник порушення здорової поведінки» О.Л. Луценко й О.Є. Габелкової (у \%)

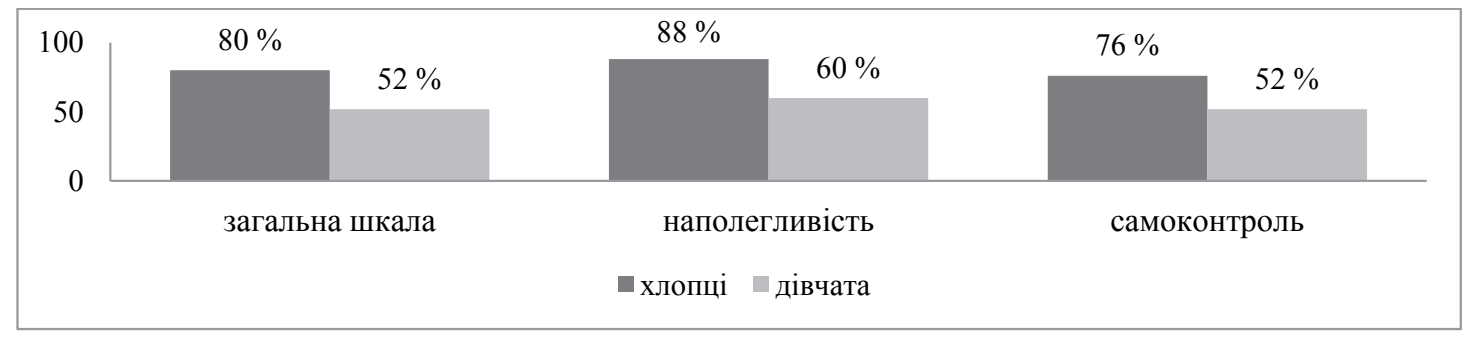

Рис. 3. Результати за методикою “Дослідження вольової саморегуляції” А.В. Звєрькова і $Є$. В. Ейдмана

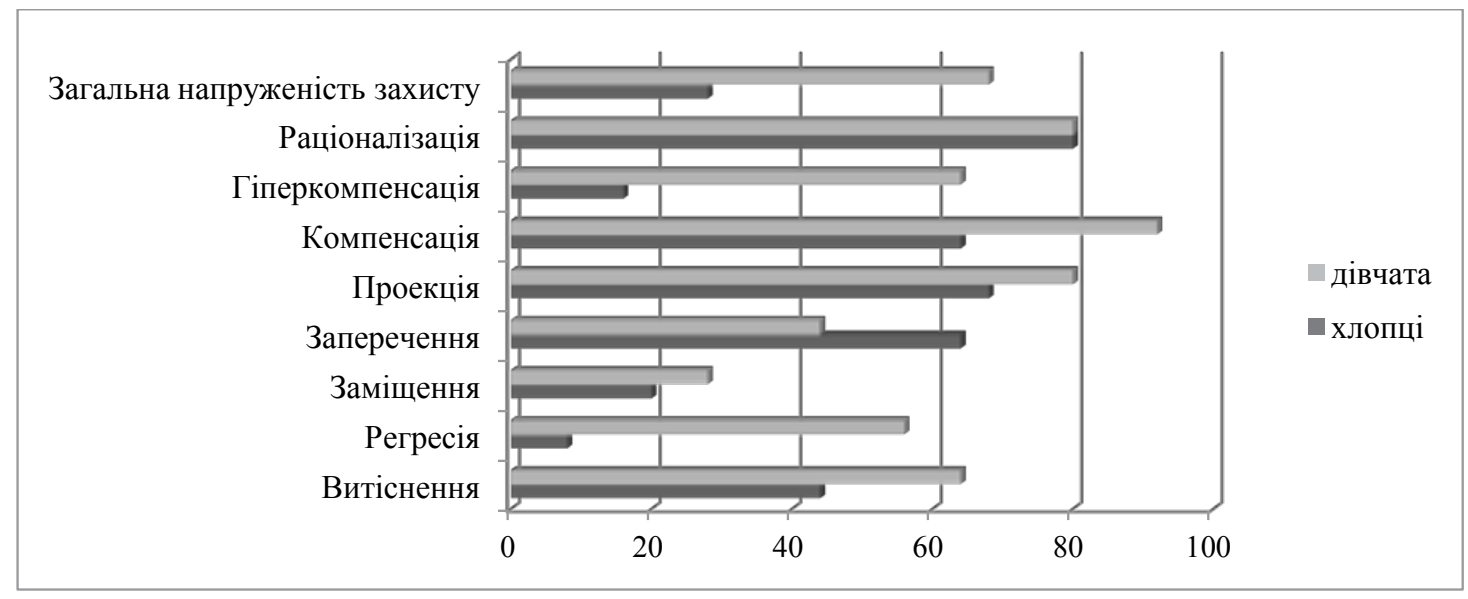

Рис. 4. Результати дослідження за методикою «Індекс життєвого стилю» Плутчика - Келлермана - Конте 
терні тяга до алкоголю й паління, нехтування безпекою, саморуйнівна поведінка, що може свідчити про наявність у них нездорової поведінки. Натомість для дівчат $€$ характерними такі порушення: гонитва за модним іміджем, порушення харчування, низький самоконтроль й емоційна некомпетентність, що також може вказувати на порушення ними здорової поведінки, хоча й незначні. Графічне представлення результатів подано на рисунках 1 i 2.

Результати, отримані за тестом-опитувальником «Дослідження вольової саморегуляції», авторами якого є А.В. Звєрьков і Є.В. Ейдман, надають нам інформацію про рівень здійснення свідомого самоконтролю та саморегуляції над власною поведінкою, думками й почуттями, дають змогу говорити, що такі риси, як настирність і наполегливість, притаманні 88\% досліджуваним хлопцям і лише $60 \%$ досліджуваним дівчатам. Це свідчить про те, що хлопці більшою мірою прагнуть до завершення розпочатої справи, ніж дівчата. Щодо такого показника, як самоконтроль, то ухлопців він розвинений краще. Так, $76 \%$ хлопців нашої вибірки й лише $52 \%$ дівчат виявилися здатними до самоконтролю, регулювання власної поведінки та планування діяльності.

Графічне представлення результатів подано на рисунку 3.

Опитувальник «Міні-мульт» (скорочений багатофакторний опитувальник для дослідження особистості MMPI в адаптації В.П. Зайцева і В.Н. Козюлі) дав нам можливість дослідити індивідуальні особливості особистості та її психічний стан. Нами було встановлено, що дівчата більше, ніж хлопці схильні до іпохондричних, істеричних, паранояльних і депресивних станів, що може свідчити про їхню підвищену емоційність, психічну вразливість і нестійкість. Для кращого сприймання отримані результати було переведено у відсотки й наочно представлено в таблиці 1.
За опитувальником «ндекс життєвого стилю» Плутчика - Келлермана - Конте було визначено, що в дівчат, імовірно, частіше спрацьовують захисні механізми психіки, ніж у хлопців, оскільки й загальна напруженість захисту в них теж значно різниться. Так, у хлопців загальна напруженість захисту становить $29 \%$, а в дівчат - 68\%. У дівчат було виявлено набагато вищий рівень проявів гіперкомпенсації, регресії, витіснення й заміщення. Натомість у хлопців значно вищий рівень прояву заперечення. Цікаво, що такий механізм, як раціоналізація, однаковою мірою притаманний як дівчатам, так і хлопцям. Отримані результати дослідження графічно представлені нами у вигляді діаграми на рисунку 4.

Беручи до уваги все вищевикладене, можна констатувати, що загалом молодь має правильне, адекватне уявлення про життєвий зміст понять «здорова поведінка» й «нездорова поведінка» 3 їхніми соціально-психологічними наслідками. Також варто відзначити відмінності між юнаками й дівчатами по ряду показників. Так, порушення здорової поведінки більш притаманне для хлопців, ніж для дівчат.

Знаннями й володіння інформацією сучасної молоді про можливий спосіб життя та його наслідки - це лише фундамент, на якому може піднятися будівля, якість якої ініціюватиметься суб'єктним, індивідуальним вибором кожного.

Висновки 3 проведеного дослідження. У сучасній психології з'явилося чимало нових концепцій психічного здоров'я та моделей здоров'я. Їхньою загальною характеристикою $€$ тенденція до централізації на основі розвитку, зростання, самореалізації, самотворення людини, здатності свідомо керувати своїми вчинками й нести відповідальність за себе перед собою й іншими, розвиненої смислової сфери, духовного піднесення.

Таблиця 1

Результати, отримані за методикою “Міні-мульт» (у \%)

\begin{tabular}{|c|c|c|c|c|c|c|}
\hline \multirow{3}{*}{ Шкали } & \multicolumn{3}{|c|}{ Хлопці } & \multicolumn{3}{|c|}{ Дівчата } \\
\hline & \multicolumn{6}{|c|}{ Рівень (у \%) } \\
\hline & високий & середній & низький & високий & середній & низький \\
\hline Брехні (L) & 12 & 64 & 24 & - & 52 & 48 \\
\hline Вірогідності (F) & 12 & 80 & 8 & 32 & 68 & $\begin{array}{ll}- \\
\end{array}$ \\
\hline Корекції (К) & - & 84 & 16 & - & 60 & 40 \\
\hline Іпохондрія (Hs) & - & 84 & 16 & - & 92 & 8 \\
\hline Депресія (D) & - & 44 & 56 & 12 & 72 & 16 \\
\hline Істерія (Нy) & - & 56 & 44 & - & 88 & 12 \\
\hline Психопатія (Pd) & 4 & 48 & 48 & 4 & 76 & 20 \\
\hline Паранояльність (Pa) & - & 60 & 40 & 28 & 64 & 8 \\
\hline Психастенія (Pt) & - & 44 & 56 & - & 92 & 8 \\
\hline Шизоїдність (Se) & 8 & 88 & 4 & 4 & 92 & 4 \\
\hline Гіпотонія (Ma) & - & 84 & 16 & 8 & 80 & 12 \\
\hline
\end{tabular}


Описуючи уявлення молоді про здорову поведінку, можна стверджувати, що загалом молодь має правильне, адекватне уявлення про життєвий зміст понять «здоровий спосіб життя» й «нездоровий спосіб життя» з їхніми соціально-психологічними наслідками. Здоровий спосіб життя є надійним потенціалом професійної ефективності, життєвого задоволення й успішності. Важливою складовою частиною процесу навчання й виховання молодого покоління є робота з формування здорового способу життя. Вона має складатися з двох взаємопов'язаних частин:

1) прийняття молоддю цінностей здорового способу життя (пропагувальна складова частина);

2) здобуття молоддю знань, умінь і навичок, необхідних для самостійного виконання вимог здорового способу життя (змістовно-інформаційна й практична складові частини) [6].

До найбільш ефективних сучасних засобів популяризації психогігієнічного виховання й здорового способу життя серед молоді (пропагувальний і змістовно-інформаційний складники) належать ЗМІ. Оскільки понад 80\% молоді дивляться щоденно телевізор, 70\% читають різні періодичні видання, то саме $3 \mathrm{MI}$ здатні опосередковано впливати на молодь через соціальні інститути, інших людей, сім'ю, друзів, ровесників. Саме тому перспективу подальших досліджень вбачаємо в розробленні відповідних пропагувально-корекційних заходів і дослідженню їхньої ефективності. Важливо в процесі розроблення та здійснення цих заходів враховувати ієрархію мотивів молоді щодо ведення здорового способу життя. Тобто пропагування має бути спрямовано на актуалізацію домінуючих мотивів (вдосконалення стану здоров'я; досягнення впевненості у своїх можливостях; вдосконалення конституційних особливостей тіла; активна форма відпочинку, дозвілля; випробовування своїх можливостей в екстремальних умовах; професійно-прикладна підготовка тощо). Але, окрім того, слід ще й активно й цілеспрямовано формувати в молоді запит, потребу на дотримання й ведення здорового способу життя.

\section{ЛІТЕРАТУРА:}

1. Амосов М.М. Роздуми про здоров'я. Київ : Здоров'я, 1990. 258 с.

2. Горностай П.П. Гендерна соціалізація та становлення гендерної ідентичності. Основи теорії гендеру: навчальний посібник. Київ : К.І.С, 2004. C. $132-155$.

3. Коцан І.Я. Психологія здоров'я людини. Луцьк : РВВ «Вежа» Волинського національного університету ім. Лесі Українки, 2011. 430 с.

4. Костикова И.В. Введение в гендерные исследования : учебное пособие. Москва : Аспект Пресс, 2005. $255 \mathrm{c}$

5. Навольская Д.В. Гендерные аспекты профеесиональных стереотипов: выбор профессии. Санкт-Петербург : Речь, 2002. С. 299-300.

6. Психологічне обґрунтування заходів пропагування психогігієнічного виховання і здорового способу життя серед сучасної молоді: колективна монограсрія / за заг. ред. С.Д. Максименка та ін. Київ : Інсрорм.-аналіт. агентство, 2012. 152 с.

7. Титаренко Т.М., Лєпіхова Л.А., Кляпець О.Я. Формування в молоді настанов на здоровий спосіб життя. Київ, 2006. 123 с. 